\title{
Treatment of dyslipidemia
}

\section{Andrew Tonkin* and Allison Byrnes}

Address: School of Public Health and Preventive Medicine, Department of Epidemiology and Preventive Medicine, 99 Commercial Road, Melbourne, Vic 3004, Australia

*Corresponding author: Andrew Tonkin (andrew.tonkin@monash.edu)

Fl000Prime Reports 2014, 6:17 (doi:10.12703/P6-17)

All FI000Prime Reports articles are distributed under the terms of the Creative Commons Attribution-Non Commercial License (http://creativecommons.org/licenses/by-nc/3.0/legalcode), which permits non-commercial use, distribution, and reproduction in any medium, provided the original work is properly cited.

The electronic version of this article is the complete one and can be found at: http://fl000.com/prime/reports/m/6/I7

\begin{abstract}
Atherosclerotic cardiovascular disease (including coronary heart disease, stroke and peripheral arterial disease) is the leading cause of death globally. Abnormal blood lipids (dyslipidemia), smoking, and high blood pressure are responsible for more than $75 \%$ of cases. Aggressive low-density lipoprotein (LDL)cholesterol lowering therapy, particularly statins, appear to be the most effective of the therapeutic approaches, but even with their use, cardiovascular disease event rates remain relatively high, underpinning the quest for novel treatments. In this review we discuss recent advances in the field and what remains to be done to reduce this rate further. In particular, in addition to development and investigation of new LDL-cholesterol lowering therapies, there has been a major focus on treatments to favorably influence high-density lipoprotein (HDL)-cholesterol and triglyceride concentrations. However, to this time, approaches to the latter have been somewhat disappointing, but they may have particular benefits in people with diabetes. As atherosclerosis is a largely preventable process, which is driven particularly by behavioral and lifestyle factors, attention to other modifiable risk factors is imperative.
\end{abstract}

\section{Introduction and context}

Atherosclerotic cardiovascular disease (CVD), including coronary heart disease (CHD), stroke and peripheral arterial disease, is the leading cause of death globally. Abnormal blood lipids (dyslipidemia), smoking, and high blood pressure are responsible for more than $75 \%$ of cases. But of nine independent risk factors for myocardial infarction (MI), dyslipidemia is associated with the highest population-attributable risk [1]. In addition, the evidence from randomized controlled trials (RCTs) supporting the importance of aggressive low-density lipoprotein (LDL)-cholesterol lowering is the most robust of various CVD therapies [2], particularly for statins [3]. However, despite use of proven therapies, event rates in RCTs remain relatively high, underpinning the quest for novel treatments. In addition to testing new approaches to LDL-cholesterol lowering, there has been a major focus on treatments that can favorably influence high-density lipoprotein (HDL)-cholesterol and triglyceride concentrations. Such therapies may have particular benefit in people with diabetes, which is associated with both a higher casefatality rate after acute coronary events and a poorer longterm prognosis [4].

\section{Recent advances Low-density lipoprotein cholesterol} Statins

There is a clear linear relationship between the degree of LDL-cholesterol lowering achieved with statins and benefits, with a $10 \%$ and $21 \%$ reduction in allcause mortality and major vascular events, respectively, per $1.0 \mathrm{mmol} / \mathrm{L}$ reduction in LDL-cholesterol [3]. This is further supported by data showing superiority of more, compared to less, intensive LDL-cholesterol lowering [3].

Benefits have been found in people with CHD, stroke, or diabetes and those who are apparently healthy. More recently, another potential use of statins arises from a meta-analysis showing a decrease in peri-procedural 
surrogates of myocardial injury following percutaneous coronary interventions [5].

Meta-analyses have also re-affirmed the overall safety of statins, with no significant increase in non-vascular mortality nor in incident or fatal cancer [3].

Statins are generally well tolerated apart from myalgia, although its frequency is higher in clinical use than in RCTs. Recent observational data in over 2 million individuals have also shown that acute renal failure may be a dose-related side effect of statins, although it has a very low incidence. Treatment of approximately 1700 persons over 12 weeks with high-dose, compared to low-dose, statin therapy was associated with one associated hospitalization [6]. Previous meta-analysis of RCTs has shown that one incident case of new type 2 diabetes might occur for every 255 individuals treated for 2 years with statins [7]. Although warnings have been issued concerning possible impairment of cognition by statins, this was based on less robust observational data. Some major outstanding questions remain concerning statins. One is their time of commencement in those who are apparently healthy.

An important analysis has compared CHD risk reduction in subjects with genotypes that impact on LDL-cholesterol concentrations throughout life and in RCTs of statins with follow-up of approximately 4-5 years [8]. There was approximately 3 -fold greater reduction in CVD death, non-fatal MI, and coronary revascularization (when the latter could be ascertained) per $1 \mathrm{mmol} / \mathrm{L}$ lower LDLcholesterol concentrations with lifetime exposure compared to that seen in RCTs.

How might appropriate candidates for early treatment be selected?

The early stages of atherosclerosis are present in many asymptomatic younger adults in the second and third decades of life [9]. Earlier commencement of statins would gain greater clinical traction were cost-effective, non-invasive means available to identify those at highest risk. Among possible indicators, a significant family history of premature CHD has the most evidence and is supported by guidelines [10]. Quantification of coronary artery calcification in intermediate-risk patients [11] is already used by many clinicians. Ideally the value of imaging and blood analytes would be tested in RCTs comparing outcomes after biomarker or image-guided screening with usual practice without such screening. However, such RCTs would have logistic difficulties and are unlikely to be undertaken.
Despite the extremely robust evidence base supporting the use of statins, other LDL-cholesterol lowering therapies are needed. This is because the LDL-cholesterol target suggested in guidelines, currently $1.8-2.0 \mathrm{mmol} / \mathrm{L}$ in highest-risk patients, is often not achieved. Patients may be intolerant of statins. Finally, in addition to the high "residual risk" despite reaching the recommended LDL-cholesterol target, more aggressive therapy may be needed in special conditions. These include familial hypercholesterolemia (FH), when LDL-cholesterol concentrations are typically above $2.6 \mathrm{mmol} / \mathrm{L}$ despite statins, and those with genetic elevation in lipoprotein(a). Indeed, FH is now thought to affect about 1 in 200 individuals, making it the most common genetically transmitted disease [12]. The potential use of combination LDLcholesterol lowering therapy is supported by modelling showing a greater impact of a further reduction of LDL cholesterol by $1 \mathrm{mmol} / \mathrm{L}$ on top of a starting dose of a statin compared simply to doubling the statin dose, which further reduces LDL cholesterol by only about $6 \%[13]$.

\section{Ezetimibe}

Ezetimibe targets the NPCILI receptor in intestinal cells to inhibit absorption of cholesterol and plant sterols [14]. Ezetimibe lowers LDL cholesterol by about $20 \%$ and its combination is rational because statins increase cholesterol absorption [15].

Initial trials investigating effects of ezetimibe on surrogate endpoints were somewhat disappointing. However, further important evidence will be provided by the IMPROVE-IT study, which is testing whether combination therapy with ezetimibe and simvastatin given to patients after acute coronary syndromes and with a target LDL cholesterol of approximately 1.4 $\mathrm{mmol} / \mathrm{L}$ reduces events compared to simvastatin alone with the present usual target of $1.8 \mathrm{mmol} / \mathrm{L}$ [16]. The trial will have a very large number of events and also provide important safety data concerning very low LDLcholesterol levels. Until its results are available, ezetimibe is often given to subjects who fail to achieve target LDL-cholesterol levels, particularly those with higher baseline LDL-cholesterol concentrations or with diabetes.

\section{Long-acting niacin formulations}

Many years ago, niacin was shown to be beneficial as monotherapy. In addition to lowering LDL cholesterol and triglycerides by about $15 \%$ and $40 \%$, respectively, HDL-cholesterol concentrations are increased by $20 \%$ $25 \%$ and lipoprotein(a) (Lp[a]) decreased by $25 \%$. However, side effects, particularly flushing, have limited 
its use. It had been hoped that longer-acting formulations, possibly associated with prostaglandin inhibition, might increase its tolerability.

Two recent trials of adding niacin to a statin in patients with CVD and possibly diabetes have disappointed.

The AIM-HIGH trial [17] in 3300 subjects with vascular disease and atherogenic dyslipidemia was very likely underpowered but showed no further reduction in vascular events with niacin-statin combination. However, on-treatment HDL and LDL concentration differences were only +4 and $-5 \mathrm{mg} / \mathrm{dL}$, respectively. More recently, the much larger HPS2-THRIVE trial [18] in approximately 27,000 patients with vascular disease and/or diabetes also showed no further reduction in events beyond statin therapy alone. However, on-treatment differences in lipid subfractions between the randomized limbs were again relatively small. In addition, in HPS-2 THRIVE, there were more side effects in those patients randomized to niacin-laropiprant, the prostaglandin inhibitor included in this formulation. Full results are still to be formally published.

\section{Bile acid sequestrants}

Non-absorbable anion-exchange resins such as cholestyramine, nonspecifically bind cholesterol-rich bile acids in the gut, increasing the breakdown of cholesterol and fecal excretion of bile salts by interrupting the enterohepatic circulation. They have a moderate effect in lowering LDL cholesterol by $10 \%-20 \%$ and were used particularly when statins could not be taken. They may increase triglyceride levels. A significant reduction in CHD events with use of cholestyramine in primary prevention was demonstrated many years ago in the LRC-CPPT [19] and in smaller secondary prevention trials. However, upper and lower gastrointestinal side effects are relatively common, and the use of resins has been largely supplanted by other agents.

\section{PCSK9 inhibitors}

Agents that inhibit proprotein convertase subtilisin/ kexin type 9 (PCSK9) are arguably the most appealing of the new therapeutic agents for lowering LDL cholesterol. Their use is plausible because of known biology [20]. PCSK9 regulates plasma concentrations of LDL cholesterol by interacting with LDL receptors on liver cells. After binding to an LDL receptor, PCSK9 directs it to lysosomal degradation. Thus, it inhibits recycling of the receptor to the surface of the hepatocyte and delays catabolism of LDL particles. Co-administration with statins also has a sound rationale because statins and some other lipid-modifying drugs upregulate PCSK9. This probably explains the quite modest dose-related increase in LDL-cholesterol lowering with statins.

Gain-in-function [21] and nonsense mutations [22] in PCSK9 are reflected in different CHD event rates. It is also relevant that homozygous individuals with complete absence of PCSK9 and very low levels or LDL cholesterol of about $0.3 \mathrm{mmol} / \mathrm{L}$ have been reported to be healthy [23].

PCSK9 inhibitors tested to date are monoclonal antibodies that reduce LDL-cholesterol concentrations by about $50 \%$ and thus far have been well tolerated in a number of trials [24]. Large phase III clinical trials are ongoing. The present agents require subcutaneous administration and have usually been given every 2 to 4 weeks. Approaches based on RNA interference and antisense therapy are under development, and the development of small molecules offers the future possibility of oral administration. Further safety data must also be obtained, partly because PCSK9 is expressed in tissues other than the liver. Present compounds can also potentially induce autoantibodies.

\section{Antisense oligonucleotides}

Mipomersen is an antisense oligonucleotide that binds to messenger RNA to prevent its translation and formation of apolipoprotein-B [20]. This in turn decreases formation of apoB-containing lipoproteins, including LDL cholesterol. Mipomersen can also decrease Lp(a) concentrations. Despite effective reduction in LDL-cholesterol levels of $40 \%-50 \%$, side effects, including injection-site reactions in almost all, influenza-like illness in many, and hepatic steatosis with elevation in liver enzymes in up to $15 \%$ of patients, are problematic. However, mipomersen has recently been approved in the US for use in patients with homozygous familial hypercholesterolemia [25] in whom need for apheresis may be minimized.

\section{MTP inhibition}

Lomitapide is the prototype microsomal triglyceride transfer protein (MTP) inhibitor. Such agents inhibit the transfer of triglyceride to apoB- 48 or apoB- 100 in intestinal and liver cells, respectively. Therefore, they decrease formation of chylomicrons and very-low-density lipoprotein (VLDL) in these two sites $[19,26]$. Inhibition of VLDL then leads to inhibition of LDL formation. Again, side effects have limited use of lomitapide, particularly increased stool frequency, hepatic steatosis, and increase in serum transaminase levels. Lomitapide has also recently been approved in the US for use in homozygous familial hypercholsterolemia. This class of 
compounds could have greater clinical use with further investigation of intestine-specific inhibitors.

\section{Thyromimetics}

Hyperthyroidism is associated with decrease in plasma cholesterol concentrations. Dextrothyroxin was investigated in the Coronary Drug Project and other studies many years ago. However, adverse events, including hyperthyroidism, led to it being abandoned. Investigation of newer agents, which may be safer and potentially reduce atherogenic lipoproteins and increase reverse cholesterol transport, is ongoing.

\section{High-density lipoprotein cholesterol and triglycerides}

HDL cholesterol has many anti-atherogenic effects. Basic studies have shown the importance of reverse cholesterol transport from the atherosclerotic plaque back to the liver. Indeed, a robust measure of efflux capacity was associated with coronary artery disease endpoints in fully adjusted models, which included both HDL cholesterol or apolipoproteinA-1 [27]. HDL cholesterol is also antiinflammatory and inhibits monocyte adhesion to the endothelium, inhibits LDL oxidation prior to its incorporation with macrophages in foam cells, inhibits thrombosis, and improves endothelial function and insulin sensitivity. In addition, strong epidemiologic data show an inverse exponential association between usual HDL-cholesterol levels and CHD risk [28]. This inverse association is maintained in patients already receiving statins, even with low LDL-cholesterol concentrations. Low HDL-cholesterol and/or elevated triglyceride concentrations, together with shift to the small dense LDL phenotype, is also the most prevalent lipid disorder in people with type 2 diabetes or the metabolic syndrome.

However, the importance of increasing HDL-cholesterol concentrations has been challenged recently. Gene variants that increase HDL-cholesterol concentrations and have no effect on LDL-cholesterol concentrations do not usually protect against CVD [29]. Particularly, published RCTs that sought to test whether increasing HDL cholesterol is protective have been disappointing [30].

\section{Fibrates}

Fibrates are weak agonists of peroxisome proliferatoractivated receptor alpha (PPAR- $\alpha$ ). A significant reduction in CHD events with gemfibrozil was shown in the Helsinki Heart Study [31] and was associated with a small reduction in LDL cholesterol, a larger reduction in triglycerides, and more than $10 \%$ increase in HDL cholesterol. In VA-HIT [32], gemfibrozil was also shown to reduce CVD events in post-MI patients with low HDL-cholesterol levels.

The FIELD [33] and ACCORD [34] RCTs were large placebo-controlled studies of fenofibrate in people with diabetes. Statins were not mandated in FIELD, but were in ACCORD. Both trials showed no reduction in macrovascular events, such as related to CHD. However, microvascular events, including retinal and renal outcomes and autonomic neuropathy, were significantly reduced. In addition, a meta-analysis has shown a reduction in macrovascular events in those with low HDL-cholesterol $(\leq 0.9 \mathrm{mmol} / \mathrm{L})$ and high triglyceride ( $\geq 2.3 \mathrm{mmol} / \mathrm{L}$ ) concentrations [35], supporting a particular role of fibrates in this context. It should also be noted that fenofibrate was associated with only a very small, if any, increase in HDL-cholesterol concentration in these trials, and the agent can possibly be regarded as impacting particularly on triglycerides, which are decreased by $30 \%$ or more, and other mechanisms, such as coagulation and inflammation. If fibrates are used, fenofibrate is the agent of choice from this class and, unlike other fibrates, it has no pharmacokinetic interaction with statins.

\section{CETP inhibitors}

Cholesteryl ester transfer protein (CETP) is associated with the transfer of cholesterol between anti-atherogenic apolipoprotein A-containing particles and pro-atherogenic apolipoprotein B particles [36]. CETP inhibition appeared to offer great potential for the treatment of dyslipidemias. However, completed large-scale trials have thus far been disappointing.

The ILLUMINATE trial [37] evaluated torcetrapib, which increased HDL cholesterol by approximately $60 \%$ and decreased LDL cholesterol by approximately $25 \%$ on the background of a statin. ILLUMINATE was terminated prematurely because of an increase in all-cause mortality and cardiovascular events in those randomized to torcetrapib. In addition, a significant increase in systolic blood pressure of 5-6 mm $\mathrm{Hg}$ was noted. Untoward effects were most likely related to off-target toxicity with an increase in levels of aldosterone and other vasoactive hormones such as cortisol. Torcetrapib also has other adverse effects by reducing expression of endothelial nitric oxide (NO) synthase and increasing expression of endothelin-I.

Dalcetrapib had little effect on LDL cholesterol but increased HDL cholesterol by approximately $30 \%$. The dal-OUTCOMES trial [38] was terminated early on the grounds of futility. In dal-OUTCOMES, dalcetrapib also 
was associated with a much smaller but still significant increase in blood pressure and in C-reactive protein levels, the latter a marker of inflammation. Both torectrapib and dalcetrapib have been withdrawn from development because of these trial results.

Large trials of the very potent CETP inhibitors anacetrapib in 30,000 subjects with occlusive arterial disease [39] and evacetrapib in 11,000 subjects at high CVD risk [40] are ongoing and their results are awaited with great interest. Initial data have shown that these agents, on a background of statin use, have very powerful and potentially beneficial effects on both HDL cholesterol (over 100\% increase) and LDL cholesterol (about 50\% decrease) and no effect on blood pressure. It is of interest that CETP gene variants impact on CHD event rates [41] but whether or not this reflects only the associated changes in HDL-cholesterol concentrations is unclear because such genetic variants are typically associated also with altered LDL-cholesterol concentrations.

RCTs ultimately test an intervention rather than operative mechanisms. A major outstanding question is whether it is HDL functionality rather than simply the number of HDL particles which is most important.

\section{Diet}

Core recommendations for the dietary management of dyslipidemia focus on dietary fat intake, particularly the amounts of saturated and trans-fat, and on cholesterol and caloric intake as well as eating a wide variety of healthy foods $[42,43]$. In addition, a number of supplements and functional foods show promise and continue to be investigated.

\section{Omega-3 poly-unsaturated fatty acids}

The omega-3 polyunsaturated fatty acids (PUFAs) are a group of three essential fatty acids found in oily fish (eicosapentaenoic acid [EPA], docosahexaenoic acid [DHA]) and in plant seeds and oils ( $\alpha$-linolenic acid [ALA]). EPA, DHA, and to a lesser extent ALA have been shown to be effective in reducing serum triglycerides [43]. They also appear to exert anti-atherogenic effects via the inhibition of thromboxane and pro-inflammatory cytokine production, leading to reduced platelet aggregation and vascular inflammation [44].

The RCT data concerning omega-3 PUFAs are inconsistent. Among trials in 2002, the GISSI-Prevenzione group [45] reported effects of omega-3 PUFAs on mortality in postMI patients. A daily dose of $1 \mathrm{~g}$ /day of PUFA was associated with an early and sustained reduction in risk of sudden death. Triglyceride concentrations were reduced slightly but significantly compared to controls; however, there was no significant overall change in total and LDLcholesterol concentrations. The authors questioned whether the outcomes (particularly at a lower dose of $1 \mathrm{~g} /$ day) could be attributable to anti-arrhythmic and antifibrillatory effects, via effects on membrane channels, which have been seen in animal studies.

The very large open-label interventional JELIS trial [46] studied the concomitant use of pravastatin or simvastatin with highly purified EPA (1.8 mg/day) against statin alone in 18,645 patients. The EPA group had a significant $19 \%$ reduction in fatal CHD events, although there was no effect on CHD or sudden cardiac death. LDL-cholesterol concentrations were not significantly changed by EPA, again suggesting effects via triglycerides or other mechanisms. It should be noted that the trial was undertaken in a Japanese population with a high background of dietary omega-3 intake, a potential confounding factor.

A more recent placebo-controlled RCT undertaken by the Risk and Prevention Study Collaborative Group [47] found that supplementation of $1 \mathrm{~g}$ combined EPA and DHA reduced triglyceride concentrations significantly $(-28.2 \pm 1.3 \mathrm{mg} / \mathrm{dL}$ vs. $-20.1 \pm 1.3 \mathrm{mg} / \mathrm{dL}, P<0.001)$, but overall had no favorable effect on clinical events in subjects with high cardiovascular risk but no previous MI. Other recent trials have also shown neutral results. These include the Alpha Omega Trial, which investigated $400 \mathrm{mg}$ EPA-DHA and $2 \mathrm{~g}$ ALA daily in post-MI survivors [48]. However, there were marginal benefits in nonstatin users.

The inconsistencies in clinical trial data quite possibly relate to the dose of omega-3 PUFAs investigated and whether or not this was on a background of statins. Larger doses of these supplements may have a particular role as one of the options in individuals who cannot tolerate statins.

At this time, the European Society of Cardiology [43] recommend an intake of at least 2-3 servings of fish per week for CVD prevention and suggest that supplementation of 2-3 g/day of EPA-DHA may be useful for reduction of triglycerides.

\section{Mediterranean diet}

The Mediterranean diet is distinguished by a regular intake of vegetables, fruit, whole grains, mono-unsaturated fats, fish, nuts, and legumes and reduced consumption of red meat and high-fat dairy products [49]. Characteristically, it provides a high intake of unsaturated fat and a low amount of saturated and trans-fat. Studies to date show 
promise for this diet in reducing cardiovascular risk factors and CVD events. Extended follow-up of the Lyon Heart Study [50] reported that a Mediterraneantype diet was associated with a large reduction in non-fatal MI and cardiac death (1.24 and 4.07 per hundred patients per year after 46 months in the intervention and control groups, respectively). Higher plasma ALA levels were also found to improve prognosis, although the same was not determined for EPA and DHA.

A 2011 meta-analysis of six trials found that the Mediterranean diet was more effective than a low-fat diet in reducing cardiovascular risk factors long-term [51]. A similar result was found by a meta-analysis of 50 studies involving 534,906 individuals, assessing effects of the diet on components of the metabolic syndrome [49]. A recent study in a Danish cohort found that adherence to the Mediterranean diet was associated with reduced all-cause mortality and cardiovascular events and mortality, but not stroke [52].

Recently, the Spanish PREDIMED [53] primary prevention trial reported a reduced risk of cardiovascular events in patients with a high CVD risk, who ingested a Mediterranean diet supplemented with either mixed nuts or extra virgin olive oil.

In the GISSI-Prevenzione trial, moderate wine intake, which is also characteristic of the Mediterranean diet, was associated with no increased risk and a potential reduced likelihood of CVD events in patients with a recent MI [54].

European guidelines [55] discuss the emerging evidence of the Mediterranean diet pattern and recommend a healthy diet for CVD prevention, which includes intake of fish, whole grains, fruit, vegetables, and alcohol in moderation and reduced saturated and trans-fat intake.

\section{Phytosterols and dietary fiber}

Phytosterols decrease serum cholesterol and LDLcholesterol concentrations by inhibiting cholesterol absorption [56]. The International Atherosclerosis Society (IAS) and European Society of Cardiology (ESC) [42,43] state that an intake of 1-2 g/day may be useful for reduction of LDL-cholesterol. Dietary fiber is also a key preventive measure for lowering LDL-cholesterol, with the IAS [42] recommending 10-25 g/day of soluble fiber alongside phytosterols.

\section{Other lifestyle factors}

Smoking cessation is fundamental in reducing CVD risk at an individual and population level. The IAS [42] also recommends an upper alcohol limit of 2 servings per day for men and 1 for women, aerobic activity for 30 minutes daily, at least 5 days per week, and maintenance of body mass index (BMI) and waist circumference within healthy ranges.

Smoking cessation, physical activity, weight reduction, and alcohol modification can increase HDL-cholesterol concentrations $[57,58]$. Alcohol modification can also have an impact on triglycerides [43].

The Look AHEAD research group recently reported a study of 5,145 patients with type 2 diabetes and a BMI of at least $25 \mathrm{~kg} / \mathrm{m}^{2}$ and showed that a multiple lifestyle intervention consisting of exercise, group meetings, and dietary restriction resulted in significant weight loss and reduction in cardiovascular disease risk factors over 4 years [59]. However, the trial was subsequently terminated early after a median of 9.6 years, on the basis of futility, when 13.5-year follow-up was planned investigating the effects on CVD events [60].

\section{Implications for clinical practice}

A major outstanding challenge is how best to implement use of evidence-based therapies in clinical practice, particularly statins. Observational data in Europe [61] and other countries throughout the world [62] have shown poor concordance with proven therapies, including statins in CHD patients. Persistence with statins is even less in those who are apparently healthy but in whom they are considered indicated. If therapies are applied particularly to those at highest risk, they are most cost-effective. In this case, supportive systems of care will often be necessary to facilitate translation of RCT evidence to improve outcomes in usual patients. Another important aspect is effective communication of the risk of future events to susceptible individuals. Among newer approaches are the concepts of heart or vascular age [63] and of lifetime or modifiable risk, particularly in relatively younger individuals who may be disadvantaged by absolute (global) risk assessment when they have relatively high modifiable risk factor levels. This is because advancing age is its major driver of risk in absolute risk algorithms such as derived from the Framingham Heart Study [64] and the SCORE project [63].

A final comment concerns lifestyle. Atherosclerosis is a largely preventable process, which is driven particularly by behavioral and lifestyle factors. Adherence to a healthy lifestyle, extending beyond nutrition alone, has been shown to improve outcomes whether or not drug therapies, including those targeting dyslipidemia, 
are being used. Different levels of government can impact enormously by enacting appropriate legislation and promoting supportive environments and other important population-wide strategies.

\section{Abbreviations}

ACCORD, Action to Control Cardiovascular Risk in Diabetes; ACCELERATE, A study of evacetrapib in highrisk vascular disease; AIM-HIGH, Atherothrombosis Intervention in Metabolic syndrome with low highdensity lipoprotein/high triglycerides: Impact on Global Health outcomes; CETP, cholesteryl ester transfer protein; CHD, coronary heart disease; CVD, cardiovascular disease; dal-OUTCOMES, Dalcetrapib Outcomes Trial; DHA, docohexaenoic acid; EPA, eicosapentaenoic acid; EUROASPIRE, EUROpean Action on Secondary and Primary prevention by Intervention to Reduce Events; FH, familial hypercholesterolemia; FIELD, Fenofibrate Intervention and Event Lowering in Diabetes trial; GISSI, The Gruppo Italiano per lo Studio della Sopravvivenza nell'Infarto Miocardico; HDL, highdensity lipoprotein; HPS2-THRIVE, Heart Protection Study 2 - Treatment of high-density lipoprotein to Reduce the Incidence of Vascular Events; IAS, International Atherosclerosis Society; ILLUMINATE, Investigation of Lipid Level Management to Understand its Impact in Atherosclerotic Events; IMPROVE-IT, IMproved Reduction of Outcomes: Vytorin Efficacy International Trial; JELIS, Japan Eicosapentaenoic acid Lipid Intervention Study; LDL, low-density lipoprotein; Lp(a), lipoprotein(a); LRC-CPPT, Lipid Research ClinicsCoronary Primary Prevention Trial; MI, myocardial infarction; MTP, Microsomal triglyceride transfer; PCSK9, protein convertase subtilisin/kexin type 9; PUFA, polyunsaturated fatty acids; RCT, randomized controlled trial; SCORE, Systematic COronary Risk Evaluation; VA-HIT, Veterans Affairs High-Density Lipoprotein Cholesterol Intervention Trial; VLDL, very low density lipoprotein.

\section{Disclosures}

Andrew Tonkin has received research funding or honoraria for Advisory Board or Safety and Data Monitoring Committee membership or lectures from Amgen (Thousand Oaks, CA, USA), AstraZeneca (London, UK), Boehringer-Ingelheim (Ingelheim, Germany), CSL Behring (King of Prussia, PA, USA), Merck Sharp Dohme (Whitehouse Station, NJ, USA), Pfizer Inc (New York, NY, USA), Sanofi (Paris, France)/ Regeneron (Tarrytown, NY, USA), and Servier (Neuillysur-Seine, France). Allison Byrnes declares that she has no disclosures.

\section{References}

I. Yusuf S, Hawken S, Ounpuu S, Dans T, Avezum A, Lanas F, McQueen M, Budaj A, Pais P, Varigos J, Lisheng L: Effect of potentially modifiable risk factors associated with myocardial infarction in 52 countries (the INTERHEART study): casecontrol study. Lancet 2004, 364:937-52.

\section{FlOOOPrime}

RECOMMENDED

2. Robinson JG, Smith B, Maheshwari N, Schrott H: Pleiotropic effects of statins: benefit beyond cholesterol reduction? $\mathrm{A}$ meta-regression analysis. J Am Coll Cardiol 2005, 46: 1855-62.

\section{FlOOOPrime}

RECOMMENDED

3. Baigent C, Blackwell L, Emberson J, Holland LE, Reith C, Bhala N, Peto R, Barnes EH, Keech A, Simes J, Collins R: Efficacy and safety of more intensive lowering of LDL cholesterol: a metaanalysis of data from 170,000 participants in 26 randomised trials. Lancet 2010, 376:1670-81.

\section{FlOOOPrime
RECOMMENDED}

4. Donahoe SM, Stewart GC, McCabe CH, Mohanavelu S, Murphy SA, Cannon CP, Antman EM: Diabetes and mortality following acute coronary syndromes. JAMA 2007, 298:765-75.

\section{FlOOOPrime
RECOMMENDED}

5. Patti G, Cannon CP, Murphy SA, Mega S, Pasceri V, Briguori C, Colombo A, Yun $\mathrm{KH}$, Jeong $\mathrm{MH}$, Kim J, Choi D, Bozbas $\mathrm{H}$ Kinoshita M, Fukuda K, Jia X, Hara H, Cay S, Di Sciascio G: Clinical benefit of statin pretreatment in patients undergoing percutaneous coronary intervention: a collaborative patient-level meta-analysis of 13 randomized studies. Circulation 20I I, I23:1622-32.

\section{FlOOOPrime}

\section{RECOMMENDED}

6. Dormuth CR, Hemmelgarn BR, Paterson JM, James MT, Teare GF, Raymond CB, Lafrance J, Levy A, Garg AX, Ernst P: Use of high potency statins and rates of admission for acute kidney injury: multicenter, retrospective observational analysis of administrative databases. BMJ 20I3, 346:f880.

\section{FlOOOPrime}

\section{RECOMMENDED}

7. Sattar N, Preiss D, Murray HM, Welsh P, Buckley BM, Craen AJM de Seshasai SRK, McMurray JJ, Freeman DJ, Jukema JW, Macfarlane PW, Packard CJ, Stott DJ, Westendorp RG, Shepherd J, Davis BR, Pressel SL, Marchioli R, Marfisi RM, Maggioni AP, Tavazzi L, Tognoni G, Kjekshus J, Pedersen TR, Cook TJ, Gotto AM, Clearfield MB, Downs JR, Nakamura H, Ohashi $Y$, et al.: Statins and risk of incident diabetes: a collaborative meta-analysis of randomised statin trials. Lancet 2010, 375:735-42.

\section{OPPrime}

RECOMMENDED

8. Ference BA, Yoo W, Alesh I, Mahajan N, Mirowska KK, Mewada A, Kahn J, Afonso L, Williams KA, Flack JM: Effect of long-term exposure to lower low-density lipoprotein cholesterol beginning early in life on the risk of coronary heart disease: a Mendelian randomization analysis. J Am Coll Cardiol 2012, 60:263I-9.

\section{FlOOOPrime}

\section{RECOMMENDED}

9. Strong JP, Malcom GT, McMahan CA, Tracy RE, Newman WP, Herderick EE, Cornhill JF: Prevalence and extent of atherosclerosis in adolescents and young adults: implications for prevention from the Pathobiological Determinants of Atherosclerosis in Youth Study. JAMA 1999, 281:727-35.

10. Greenland P, Alpert JS, Beller GA, Benjamin EJ, Budoff MJ, Fayad ZA, Foster E, Hlatky MA, Hodgson JM, Kushner FG, Lauer MS, Shaw LJ, 
Smith SC, Taylor AJ, Weintraub WS, Wenger NK, Jacobs AK, Anderson JL, Albert N, Buller CE, Creager MA, Ettinger SM, Guyton RA, Halperin JL, Hochman JS, Nishimura R, Ohman EM, Page RL, Stevenson WG, Tarkington LG, et al:: 2010 ACCF/AHA guideline for assessment of cardiovascular risk in asymptomatic adults: a report of the American College of Cardiology Foundation/American Heart Association Task Force on Practice Guidelines. J Am Coll Cardiol 2010, 56:e50-103.

1I. Polonsky TS, McClelland RL, Greenland P: Coronary Artery Calcium Score and Risk Classification for Coronary Heart Disease Prediction: The Multi-Ethnic Study of Atherosclerosis. JAMA 2010, 303:1610-6.

12. Nordestgaard BG, Chapman MJ, Humphries SE, Ginsberg HN, Masana L, Descamps OS, Wiklund O, Hegele RA, Raal FJ, Defesche JC, Wiegman A, Santos RD, Watts GF, Parhofer KG, Hovingh GK, Kovanen PT, Boileau C, Averna M, Borén J, Bruckert E, Catapano AL, Kuivenhoven JA, Pajukanta P, Ray K, Stalenhoef AFH, Stroes E, Taskinen M, Tybjærg-Hansen A: Familial hypercholesterolaemia is underdiagnosed and undertreated in the general population: guidance for clinicians to prevent coronary heart disease: Consensus Statement of the European Atherosclerosis Society. Eur Heart J 20I3, 34:3478-90.

\section{FlOOOPrime}

13. Laufs $U$, Weintraub WS, Packard C]: Beyond statins: what to expect from add-on lipid regulating therapy? Eur Heart J 2013, 34:2660-5.

\section{FlOOOPrime RECOMMENDED}

14. Sehayek E: Genetic regulation of cholesterol absorption and plasma plant sterol levels: commonalities and differences. J Lipid Res 2003, 44:2030-8.

15. Sudhop T, Reber M, Tribble D, Sapre A, Taggart W, Gibbons P, Musliner T, Bergmann K von, Lütjohann D: Changes in cholesterol absorption and cholesterol synthesis caused by ezetimibe and/or simvastatin in men. J Lipid Res 2009, 50:2117-23.

16. Cannon CP, Giugliano RP, Blazing MA, Harrington RA, Peterson JL, Sisk CM, Strony J, Musliner TA, McCabe CH, Veltri E, Braunwald E, Califf RM: Rationale and design of IMPROVE-IT (IMProved Reduction of Outcomes: Vytorin Efficacy International Trial): comparison of ezetimbe/simvastatin versus simvastatin monotherapy on cardiovascular outcomes in patients with acute coronary syndromes. Am Heart J 2008, 156:826-32.

\section{FlOOOPrime}

\section{RECOMMENDED}

17. Boden WE, Probstfield JL, Anderson T, Chaitman BR, DesvignesNickens P, Koprowicz K, McBride R, Teo K, Weintraub W: Niacin in patients with low HDL cholesterol levels receiving intensive statin therapy. N Engl J Med 20II, 365:2255-67.

18. HPS2-THRIVE Collaborative Group. HPS2-THRIVE randomized placebo-controlled trial in 25673 high-risk patients of ER niacin/laropiprant: trial design, pre-specified muscle and liver outcomes, and reasons for stopping study treatment. Eur Heart J 2013, 34:1279-91.

19. Gordon DJ, Knoke J, Probstfield JL, Superko R, Tyroler HA: Highdensity lipoprotein cholesterol and coronary heart disease in hypercholesterolemic men: the Lipid Research Clinics Coronary Primary Prevention Trial. Circulation 1986, 74:1217-25.

20. Joy TR: Novel therapeutic agents for lowering low density lipoprotein cholesterol. Pharmacol Ther 2012, 135:31-43.

21. Abifadel M, Varret M, Rabès J, Allard D, Ouguerram K, Devillers M, Cruaud C, Benjannet S, Wickham L, Erlich D, Derré A, Villéger L, Farnier M, Beucler I, Bruckert E, Chambaz J, Chanu B, Lecerf J, Luc G, Moulin P, Weissenbach J, Prat A, Krempf M, Junien C, Seidah NG,
Boileau C: Mutations in PCSK9 cause autosomal dominant hypercholesterolemia. Nat Genet 2003, 34:154-6.

\section{FIOOOPrime}

22. Cohen JC, Boerwinkle E, Mosley TH, Hobbs HH: Sequence variations in PCSK9, low LDL, and protection against coronary heart disease. $N$ Engl J Med 2006, 354: I264-72.

\section{FlOOOPrime}

\section{RECOMMENDED}

23. Zhao Z, Tuakli-Wosornu Y, Lagace TA, Kinch L, Grishin NV, Horton JD, Cohen JC, Hobbs HH: Molecular characterization of loss-of-function mutations in PCSK9 and identification of a compound heterozygote. Am J Hum Genet 2006, 79:5 14-23.

\section{FlOOOPrime
RECOMMENDED}

24. Tonkin AM, Watts GF: Into the future: diversifying lipid management. Lancet 2012, 380:1971-4.

25. Raal FJ, Santos RD, Blom DJ, Marais AD, Charng M, Cromwell WC Lachmann RH, Gaudet D, Tan JL, Chasan-Taber S, Tribble DL, Flaim JD, Crooke ST: Mipomersen, an apolipoprotein B synthesis inhibitor, for lowering of LDL cholesterol concentrations in patients with homozygous familial hypercholesterolaemia: a randomised, double-blind, placebo-controlled trial. Lancet 2010, 375:998-1006.

\section{FlOOOPrime} RECOMMENDED

26. Samaha FF, McKenney J, Bloedon LT, Sasiela WJ, Rader DJ: Inhibition of microsomal triglyceride transfer protein alone or with ezetimibe in patients with moderate hypercholesterolemia. Nat Clin Pract Cardiovasc Med 2008, 5:497-505.

27. Khera AV, Cuchel M, La Llera-Moya M de, Rodrigues A, Burke MF, Jafri K, French BC, Phillips JA, Mucksavage ML, Wilensky RL, Mohler ER, Rothblat GH, Rader DJ: Cholesterol efflux capacity, high-density lipoprotein function, and atherosclerosis. $N$ Engl 」 Med 201 I, 364:127-35.

\section{FlOOOPrime}

\section{RECOMMENDED}

28. Di Angelantonio E, Sarwar N, Perry P, Kaptoge S, Ray KK, Thompson A, Wood AM, Lewington S, Sattar N, Packard CJ, Collins R, Thompson SG, Danesh J: Major lipids, apolipoproteins, and risk of vascular disease. JAMA 2009, 302:1993-2000.

\section{FlOOOPrime
RECOMMENDED}

29. Voight BF, Peloso GM, Orho-Melander M, Frikke-Schmidt R, Barbalic M, Jensen MK, Hindy G, Hólm H, Ding EL, Johnson T, Schunkert H, Samani NJ, Clarke R, Hopewell JC, Thompson JF, Li M, Thorleifsson G, Newton-Cheh C, Musunuru K, Pirruccello JP, Saleheen D, Chen L, Stewart AFR, Schillert A, Thorsteinsdottir U, Thorgeirsson G, Anand S, Engert JC, Morgan T, Spertus J, et al.: Plasma HDL cholesterol and risk of myocardial infarction: a mendelian randomisation study. Lancet 20I2, 380:572-80.

\section{FlOOOPrime}

\section{RECOMMENDED}

30. Briel M, Ferreira-Gonzalez I, You J], Karanicolas PJ, AkI EA, Wu P, Blechacz B, Bassler D, Wei X, Sharman A, Whitt I, Alves da Silva S, Khalid Z, Nordmann AJ, Zhou Q, Walter SD, Vale N, Bhatnagar N, O’Regan C, Mills EJ, Bucher HC, Montori VM, Guyatt GH: Association between change in high density lipoprotein cholesterol and cardiovascular disease morbidity and mortality: systematic review and meta-regression analysis. BMJ 2009, 338:b92.

\section{FlOOOPrime}

3I. Frick MH, Elo O, Haapa K, Heinonen OP, Heinsalmi P, Helo P, Huttunen JK, Kaitaniemi P, Koskinen P, Manninen V: Helsinki Heart Study: primary-prevention trial with gemfibrozil in middleaged men with dyslipidemia. Safety of treatment, changes in 
risk factors, and incidence of coronary heart disease. $N$ Engl J Med 1987, 3 I 7: 1237-45.

32. Rubins HB, Robins SJ, Collins D, Fye CL, Anderson JW, Elam MB, Faas FH, Linares E, Schaefer EJ, Schectman G, Wilt T], Wittes J: Gemfibrozil for the secondary prevention of coronary heart disease in men with low levels of high-density lipoprotein cholesterol. Veterans Affairs High-Density Lipoprotein Cholesterol Intervention Trial Study Group. N Engl J Med I999, 34 I:4 I 0-8.

33. Keech A, Simes RJ, Barter P, Best J, Scott R, Taskinen MR, Forder P, Pillai A, Davis T, Glasziou P, Drury P, Kesäniemi YA, Sullivan D, Hunt D, Colman P, d'Emden M, Whiting M, Ehnholm C, Laakso M: Effects of long-term fenofibrate therapy on cardiovascular events in 9795 people with type 2 diabetes mellitus (the FIELD study): randomised controlled trial. Lancet 2005, 366:|849-6I.

\section{FlOOOPrime \\ RECOMMENDED}

34. Ginsberg HN, Elam MB, Lovato LC, Crouse JR, Leiter LA, Linz P, Friedewald WT, Buse JB, Gerstein HC, Probstfield J, Grimm RH, Ismail-Beigi F, Bigger JT, Goff DC, Cushman WC, Simons-Morton DG, Byington RP: Effects of combination lipid therapy in type $\mathbf{2}$ diabetes mellitus. N Engl J Med 2010, 362:1563-74.

\section{FIOOOPrime \\ RECOMMENDED}

35. Sacks FM, Carey VJ, Fruchart J: Combination lipid therapy in type 2 diabetes. $N$ Engl J Med 2010, 363:692-4; author reply 694-5.

\section{FIOOOPrime}

\section{RECOMMENDED}

36. Brewer HB, Santamarina-Fojo S: Clinical significance of highdensity lipoproteins and the development of atherosclerosis: focus on the role of the adenosine triphosphate-binding cassette protein Al transporter. Am J Cardiol 2003, 92: I0K-I6K.

37. Barter PJ, Caulfield M, Eriksson M, Grundy SM, Kastelein JJP, Komajda M, Lopez-Sendon J, Mosca L, Tardif J, Waters DD, Shear CL, Revkin JH, Buhr KA, Fisher MR, Tall AR, Brewer B: Effects of torcetrapib in patients at high risk for coronary events. N Engl J Med 2007, 357:2109-22.

\section{FlOOOPrime} RECOMMENDED

38. Schwartz GG, Olsson AG, Abt M, Ballantyne CM, Barter PJ, Brumm J, Chaitman BR, Holme IM, Kallend D, Leiter LA, Leitersdorf E, McMurray JJV, Mundl H, Nicholls SJ, Shah PK, Tardif J, Wright RS: Effects of dalcetrapib in patients with a recent acute coronary syndrome. $N$ Engl J Med 2012, 367:2089-99.

\section{FlOOOPrime
RECOMMENDED}

39. CTSU University of Oxford: REVEAL: Randomized Evaluation of the Effects of Anacetrapib Through Lipid-modification. ClinicalTrials.gov Identifier: NCT0I252953; 20I3. [http://clinicaltrials .gov/show/NCT01252953].

40. Eli Lilly and Company: A study of Evacetrapib in high-risk vascular disease (ACCELERATE). ClinicalTrials.gov Identifier: NCTO I687998; 20 I3. [http://clinicaltrials.gov/show/NCTOI687998].

4I. Thompson A, Di Angelantonio E, Sarwar N, Erqou S, Saleheen D, Dullaart RPF, Keavney B, Ye Z, Danesh J: Association of cholesteryl ester transfer protein genotypes with CETP mass and activity, lipid levels, and coronary risk. JAMA 2008, 299:2777-88

42. An International Atherosclerosis Society Position Paper: Global recommendations for the management of dyslipidemia; 2013. [http://www.athero.org/IASPositionPaper.asp].

43. Reiner Z, Catapano AL, Backer G de, Graham I, Taskinen M, Wiklund O, Agewall S, Alegria E, Chapman MJ, Durrington P, Erdine S, Halcox J, Hobbs R, Kjekshus J, Filardi PP, Riccardi G, Storey RF, Wood D: ESC/EAS Guidelines for the management of dyslipidaemias: the Task Force for the management of dyslipidaemias of the European Society of Cardiology (ESC) and the European Atherosclerosis Society (EAS). Eur Heart 201।, 32:1769-818

FIOOOPrime
RECOMMENDED

44. Simopoulos AP: Evolutionary aspects of diet, the omega-6/ omega-3 ratio and genetic variation: nutritional implications for chronic diseases. Biomed Pharmacother 2006, 60:502-7.

45. Marchioli R, Barzi F, Bomba E, Chieffo C, Di Gregorio D, Di Mascio R, Franzosi MG, Geraci E, Levantesi G, Maggioni AP, Mantini L, Marfisi RM, Mastrogiuseppe G, Mininni N, Nicolosi GL, Santini M, Schweiger C, Tavazzi L, Tognoni G, Tucci C, Valagussa F: Early protection against sudden death by $n-3$ polyunsaturated fatty acids after myocardial infarction: time-course analysis of the results of the Gruppo Italiano per lo Studio della Sopravvivenza nell'Infarto Miocardico (GISSI)-Prevenzione. Circulation 2002, 105: 1897-903.

46. Yokoyama $M$, Origasa $H$, Matsuzaki $M$, Matsuzawa $Y$, Saito $Y$, Ishikawa Y, Oikawa S, Sasaki J, Hishida H, Itakura H, Kita T, Kitabatake A, Nakaya N, Sakata T, Shimada K, Shirato K: Effects of eicosapentaenoic acid on major coronary events in hypercholesterolaemic patients (JELIS): a randomised open-label, blinded endpoint analysis. Lancet 2007, 369:1090-8.

\section{FlOOOPrime}

\section{RECOMMENDED}

47. Roncaglioni MC, Tombesi M, Avanzini F, Barlera S, Caimi V, Longoni $\mathrm{P}$, Marzona I, Milani V, Silletta MG, Tognoni G, Marchioli R: n-3 fatty acids in patients with multiple cardiovascular risk factors. N Engl J Med 2013, 368:1800-8.

\section{FIOOOPRIME
RECOMMENDED}

48. Kromhout D, Giltay EJ, Geleijnse JM: n-3 fatty acids and cardiovascular events after myocardial infarction. $N$ Engl J Med 2010, 363:2015-26.

49. Kastorini C, Milionis HJ, Esposito K, Giugliano D, Goudevenos JA, Panagiotakos DB: The effect of Mediterranean diet on metabolic syndrome and its components: a meta-analysis of $\mathbf{5 0}$ studies and 534,906 individuals. J Am Coll Cardiol 20 I I, 57:I299-3 I3.

\section{FlOOOPrime
RECOMMENDED}

50. Lorgeril M de, Salen P, Martin JL, Monjaud I, Delaye J, Mamelle N: Mediterranean diet, traditional risk factors, and the rate of cardiovascular complications after myocardial infarction: final report of the Lyon Diet Heart Study. Circulation 1999, 99:779-85.

\section{FlOOOPrime}

RECOMMENDED

5I. Nordmann AJ, Suter-Zimmermann K, Bucher HC, Shai I, Tuttle KR, Estruch R, Briel M: Meta-analysis comparing Mediterranean to low-fat diets for modification of cardiovascular risk factors. Am J Med 20II, I 24:84I-5I.e2.

\section{FIOOOPrime
RECOMMENDED}

52. Tognon G, Lissner L, Sæbye D, Walker KZ, Heitmann BL: The Mediterranean diet in relation to mortality and CVD: a Danish cohort study. Br J Nutr 2013:I-9.

\section{FIOOOPrime
RECOMMENDED}

53. Estruch R, Ros E, Salas-Salvadó J, Covas M, Corella D, Arós F, GómezGracia E, Ruiz-Gutiérrez V, Fiol M, Lapetra J, Lamuela-Raventos RM, Serra-Majem L, Pintó X, Basora J, Muñoz MA, Sorlí JV, Martínez JA, Martínez-González MA: Primary prevention of cardiovascular disease with a Mediterranean diet. N EnglJ Med 2013, 368: I 279-90.

\section{FlOOOPrime}

\section{RECOMMENDED}

54. Levantesi G, Marfisi R, Mozaffarian D, Franzosi MG, Maggioni A, Nicolosi GL, Schweiger C, Silletta M, Tavazzi L, Tognoni G, 
Marchioli R: Wine consumption and risk of cardiovascular events after myocardial infarction: results from the GISSIPrevenzione trial. Int J Cardiol 2013, 163:282-7.

55. Perk J, Backer G de, Gohlke H, Graham I, Reiner Z, Verschuren M, Albus C, Benlian P, Boysen G, Cifkova R, Deaton C, Ebrahim S, Fisher M, Germano G, Hobbs R, Hoes A, Karadeniz S, Mezzani A, Prescott E, Ryden L, Scherer M, Syvänne M, Scholte op Reimer WJM, Vrints C, Wood D, Zamorano JL, Zannad F: European Guidelines on cardiovascular disease prevention in clinical practice (version 20I2). The Fifth Joint Task Force of the European Society of Cardiology and Other Societies on Cardiovascular Disease Prevention in Clinical Practice (constituted by representatives of nine societies and by invited experts). Eur Heart J 2012, 33:1635-701.

\section{FIOOOPrime}

56. Ostlund RE: Phytosterols, cholesterol absorption and healthy diets. Lipids 2007, 42:41-5.

57. Rahilly-Tierney C, Sesso HD, Djoussé L, Gaziano JM: Lifestyle changes and |4-year change in high-density lipoprotein cholesterol in a cohort of male physicians. Am Heart J 2011, 161:712-8.

58. Gepner AD, Piper ME, Johnson HM, Fiore MC, Baker TB, Stein JH: Effects of smoking and smoking cessation on lipids and lipoproteins: outcomes from a randomized clinical trial. Am Heart J 2011, 161:145-5I.

59. Unick JL, Beavers D, Bond DS, Clark JM, Jakicic JM, Kitabchi AE, Knowler WC, Wadden TA, Wagenknecht LE, Wing RR: The longterm effectiveness of a lifestyle intervention in severely obese individuals. Am J Med 2013, I 26:236-42, 242.el-2.
60. Wing RR, Bolin P, Brancati FL, Bray GA, Clark JM, Coday M, Crow RS, Curtis JM, Egan CM, Espeland MA, Evans M, Foreyt JP, Ghazarian S, Gregg EW, Harrison B, Hazuda HP, Hill JO, Horton ES, van Hubbard S, Jakicic JM, Jeffery RW, Johnson KC, Kahn SE, Kitabchi AE, Knowler WC, Lewis CE, Maschak-Carey BJ, Montez MG, Murillo A, Nathan DM, et al.: Cardiovascular effects of intensive lifestyle intervention in type 2 diabetes. $N$ Engl J Med 2013, 369: 145-54.

\section{FlOOOPrime}

RECOMMENDED

61. Kotseva K, Wood D, Backer G de, Bacquer D de, Pyörälä K, Reiner Z, Keil U: EUROASPIRE III. Management of cardiovascular risk factors in asymptomatic high-risk patients in general practice: cross-sectional survey in 12 European countries. Eur J Cardiovasc Prev Rehabil 2010, 17:530-40.

62. Yusuf S, Islam S, Chow CK, Rangarajan S, Dagenais G, Diaz R, Gupta R, Kelishadi R, lqbal R, Avezum A, Kruger A, Kutty R, Lanas F, Lisheng L, Wei L, Lopez-Jaramillo P, Oguz A, Rahman O, Swidan H, Yusoff K, Zatonski W, Rosengren A, Teo KK: Use of secondary prevention drugs for cardiovascular disease in the community in high-income, middle-income, and low-income countries (the PURE Study): a prospective epidemiological survey. Lancet 20II, 378: I23I-43.

63. Cuende Jl, Cuende N, Calaveras-Lagartos J: How to calculate vascular age with the SCORE project scales: a new method of cardiovascular risk evaluation. Eur Heart J 20I0, 31:235I-8.

64. D'Agostino RB, Vasan RS, Pencina MJ, Wolf PA, Cobain M, Massaro JM, Kannel WB: General cardiovascular risk profile for use in primary care: the Framingham Heart Study. Circulation 2008, I 17:743-53. 